\title{
DAMPAK PROGRAM KAKAO BERKELANJUTAN TERHADAP PEMBERDAYAAN PETANI DAN PENGUATAN KELOMPOK TANI (Study Kasus pada Kelompok Tani Kakao di Kabupaten Majene, Sul-bar)
}

\author{
Nurliani', Iskandar Hasan', Busmar² \\ ${ }^{1)}$ Dosen Program Studi Magister Agroekoteknologi, Konsentrasi Agribisnis, \\ Pascasarjana Universitas Muslim Indonesia \\ ${ }^{2)}$ MahasiswaProgram Studi Magister Agroekoteknologi, Konsentrasi Agribisnis, \\ Pascasarjana Universitas Muslim Indonesia \\ ${ }^{1)}$ Email : nurliani.karman@umi.ac.id \\ ${ }^{2)}$ Email : busmar.sp.mp@gmail.com
}

\begin{abstract}
This study aims to identify the implementation of the Sustainable Cocoa Program in Majene Regency, West Sulawesi Province, to identify the impact of the Sustainable Cocoa Program on the empowerment of cocoa farmers in Majene Regency, West Sulawesi Province, to know and analyze the impact of the Sustainable Cocoa Program on strengthening farmer groups in Majene Regency, West Sulawesi Province. This research was carried out by Majene Regency. The population in this study were all farmer groups that carried out a sustainable Cocoa Program, amounting to 25 farmer groups. The determination of the research sample used a purposive sampling method, namely choosing 2 farmers (1 administrator and 1 member) from each farmer group, so that the total sample was 50 farmers. Analysis of the data used descriptively to analyze the impact of the program on strengthening farmer groups, namely conducting an R-O-N analysis (Resource-Organization, and Norm). The impact of the sustainable cocoa program on training, mentoring, seedling assistance, and work wage assistance has made farmers more active in caring for their cocoa farming. The impact of the sustainable cocoa program on training activities is that respondents carry out fertilizing, planting, spraying, harvesting, pruning, and sanitation activities that are not in accordance with the training material. The impact of the sustainable cocoa program on seedling assistance is 7,404 trees / farmer groups and capital assistance for work wages is Rp. 5,665,000 / group. The ultimate goal of a sustainable cocoa program for strengthening farmer groups is no capital fertilization, active participation in counseling, active extension workers. Classroom skills, complete organization, existing functions and roles of administrators, mutual cooperation activities already in place and existing division of tasks in farmer groups.
\end{abstract}

Keywords : Pemberdayaan; Penguatan; Kelompok Tani; Kakao

PENDAHULUAN

Kakao pada saat ini ditanam di 50 negara di dunia dengan produksi total sebesar 3.045.000 ton, tingkat kenaikan produksi 2,3\% pertahun, dan $73 \%$ produksi biji kakao dunia dipasok oleh tiga besar Negara penghasil biji kakao, yaitu Pantai Gading 1.315.000 ton, Ghana 490.000 ton dan Indonesia 425.000 ton (Lass, 2004). Selanjutnya produktivitas kakao Indonesia sebesar 800 $\mathrm{kg} / \mathrm{ha}$ dan $18,4 \%$. Sedangkan bentuk ekspor kakao yaitu biji kakao dengan 15,6\% (www.FAO.org.2010).

Indonesia mempunyai potensi untuk menjadi produsen utama kakao dunia, apabila berbagai permasalahan utama yang dihadapi perkebunan kakao dapat diatasi dan agribisnis kakao dikembangkan dan dikelola secara baik. 
Indonesia masih memiliki lahan potensial seperti Sulawesi Barat melalui potensial yang cukup besar untuk program Gernas Kakao. Namun program pengembangan kakao, yaitu lebih dari tersebut tidak berjalan lancar karena 6,2 juta ha terutama di Papua, berbagai kendala antara lain: terbatasnya Kalimantan Timur, Sulawesi Tengah, ketersediaan bahan tanam, terbatasnya Sulawesi Tenggara, dan Maluku (Pusat tenaga pembina dan masih belum Penelitian dan Pengembangan Tanah memadainya dukungan perbankan. Untuk dan Agroklimat, 2005). Disisi lain membantu mengatasi masalah tersebut situasi perkakaoan dunia beberapa tahun maka pemerintah kembali mencanangkan terakhir sering mengalami defisit, tentang Kakao berkelanjutan, dengan sehingga harga kakao dunia stabil pada menggunakan analisis prospektif, dapat tingkat yang tinggi. Kondisi ini memberikan beberapa alternatif solusi merupakan suatu peluang yang baik yang terbaik di dalam pengembangan untuk segera dimanfaatkan. Upaya kakao di Sulawesi Barat.

peningkatan produksi kakao mempunyai Adapun faktor strategis yang arti yang strategis karena pasar ekspor mempengaruhi pengembangan dan biji kakao Indonesia masih sangat keberlanjutan perkebunan kakao di terbuka dan pasar domestik masih belum Sulawesi Barat yaitu: ketersediaan tergarap.

teknologi, tenaga pembina, pelatihan Beberapa tahun terakhir, petani, dukungan kebijakan, luas perkebunan kakao (Theobroma cacao L.) perkebunan kakao, produktivitas, Indonesia menghadapi permasalahan yang keterampilan petani dan kelembagaan serius dengan mengganasnya serangan ekonomi petani. Kedelapan faktor faktor hama dan penyakit tanaman kakao. strategis tersebut umumnya berada pada Produktivitas perkebunan kakao di kondisi moderat dan mengarah ke kondisi beberapa sentra produksi utama kakao optimistis karena pencanangan Indonesia mengalami penurunan yang pengembangan perkebunan kakao di cukup tajam. Oleh karena itu pemerintah Sulawesi Barat.

berupaya untuk mengurangi dampak Kakao merupakan salah satu penurunan produksi dengan memacu komoditas perkebunan yang mempunyai peningkatan produksi di daerah yang peranan cukup penting dalam 
perekonomian nasional, khususnya yaitu memilih 2 petani ( 1 pengurus dan 1 sebagai penyedia lapangan kerja, sumber anggota ) dari setiap kelompok tani, pendapatan dan devisa negara. Salah satu sehingga sample seluruhnya adalah 50 daerah yang cukup intensif dalam petani. Analisi data yang digunakan mengembangkan komoditas kakao adalah dalam penelitian ini adalah analisis Kabupaten Majene. Luas area tanaman deskriptif dan menganalisis dampak kakao di Kabupaten Majene mencapai Program terhadap pemberdayaan petani. 13.167,50 ha dengan produksi rata-rata Analisis data deskriptif menggambarkan $906 \mathrm{~kg} / \mathrm{ha}$ dengan melibatkan 11.634,00 kepala keluarga (KK) tani. Di Kabupaten Majene terdapat delapan kecamatan yang mengembangkan tanaman kakao.

Tujuan penelitian ini adalah untuk mengidentifikasi pelaksanaan program kakao berkelanjutan, dampak program pelaksanaan Program Kakao Berkelanjutan. Sedangkan menganalisis dampak Program terhadap pemberdayaan petani dipergunakan untuk menganalisis kegiatan pelatihan budidaya kakao dan pendampingan petani oleh penyuluh (PPL)

kakao berkelanjutan terhadap pemberdayaan petani kakao dan untuk menganalisis dampak program kakao berkelanjutan terhadap penguatan kelompok tani di Kabupaten Majene Provinsi Sulawesi Barat.

\section{METODE PENELITIAN}

Penelitian ini dilaksanakan di Kabupaten Majene, Sulawesi Barat. Populasi dalam penelitian ini adalah seluruh kelompok tani yang melaksanakan program kakao berkelanjutan, berjumlah 25 kelompok tani. Penentuan sample penelitian menggunakan metode purposive sampling

\section{HASIL DAN PEMBAHASAN \\ Pelaksanaan Program Kakao Berkelanjutan}

Dalam rangka meningkatkan produksi dan mutu kakao pada tahun 2009 sampai 2013 telah dilaksanakan Gerakan Nasional Peningkatan Produksi dan Mutu Kakao seluas 457.963 ha termasuk di dalamnya kegiatan peremajaan seluas 80.180 ha. Setelah tahun 2013 pemerintah tetap memperhatikan kakao sebagai komoditas strategis baik untuk petani muapun bagi devisa negara. Untuk itu pada tahun 2015 pemerintah melaksanakan pengembangan kakao 
berkelanjutan disamping melalui APBN untuk ditetapkan sebagai petani peserta. Murni juga melalaui APBN-P. Dalam Bagi satker tidak mandiri penetapan rangka melaksanakan program kakao $\mathrm{CP} / \mathrm{CL}$ sebagai petani peserta oleh Kepala berkelanjutan perlu di laksanakan Dinas Provinsi yang membidangi kegiatan : tujuan, sasaran, jenis kegiatan, perkebunan atas usulan Kepala Dinas dan penetapan petani peserta. Dinas Kabupaten yang membidangi perkebunan. Kabupaten yang membidang perkebunan Pemberdayaan Petani Kakao

melakukan inventarisasi CP/CL. Seleksi Kegiatan Program Kakao calon petani peserta dilakukan Berkelanjutan dikabupaten Majene berdasarkan persyaratan. Kemudian calon memberikan dampak terhadap petani peserta hasil inventarisasi pemberdayaan petani kakao melalui ditetapkan Kepala Dinas Kabupaten yang berbagai kegiatan. Kegiatan pelatihan dan membidangi Perkebunan atas nama Bupati pendampingan. Adapun pelaksanaan setelah berkoordinasi dengan Dinas kegiatan pelatihan dan pendampingan Provinsi yang membidangi perkebunan, meliputi kegiatan sebagai berikut :

1. Pelatihan dan pendampingan

a. Teknik Pemupukan

Tabel 1 Respon petani terhadap pelaksanaan kegiatan pemupukan dalam Program Kakao Berkelanjutan di Kabupaten Majene pada Tahun 2018.

\begin{tabular}{clccc}
\hline \hline No & Kriteria skor & Skor & Responden & Jumlah Skor \\
\hline \hline 1 & Sesuai anjuran & 3 & 15 & 45 \\
2 & Kurang sesuai & 2 & 25 & 48 \\
3 & Tidak sesuai & 1 & 10 & 11 \\
\hline \hline & Jumlah & & $\mathbf{5 0}$ & $\mathbf{1 0 4}$ \\
\hline \hline
\end{tabular}

Sumber : Lampiran 2

b. Teknik Penanaman

Tabel 2 Respon petani terhadap pelaksanaan teknik penanaman dalam Program Kakao Berkelanjutan di Kabupaten Majene pada Tahun 2018.

\begin{tabular}{clccc}
\hline \hline No & Kriteria skor & Skor & Responden & Jumlah Skor \\
\hline \hline 1 & Sesuai anjuran & 3 & 19 & 57 \\
2 & Kurang sesuai & 2 & 17 & 34 \\
3 & Tidak sesuai & 1 & 14 & 14 \\
\hline \hline & Jumlah & & 50 & 105 \\
\hline \hline
\end{tabular}

Sumber : Lampiran 2 
Busmar : Dampak Program Kakao Berkelanjutan terhadap Pemberdayaan Petani dan Penguatan Kelompok Tani.

\section{c. Teknik Penyemprotan}

Tabel 3 Respon petani terhadap pelaksanaan teknik penyemprotan dalam Program Kakao Berkelanjutan di Kabupaten Majene pada Tahun 2018.

\begin{tabular}{clccc}
\hline \hline No & Kriteria skor & Skor & Responden & Jumlah Skor \\
\hline \hline 1 & Sesuai anjuran & 3 & 6 & 18 \\
2 & Kurang sesuai & 2 & 26 & 52 \\
3 & Tidak sesuai & 1 & 18 & 18 \\
\hline \hline & Jumlah & 50 & 88 \\
\hline \hline
\end{tabular}

Sumber : Lampiran 2

d. Teknik Pemangkasan

Tabel 4 Respon petani terhadap pelaksanaan teknik pemangkasan dalam Program Kakao Berkelanjutan di Kabupaten Majene pada Tahun 2018.

\begin{tabular}{clccc}
\hline \hline No & Kriteria skor & Skor & Responden & Jumlah Skor \\
\hline \hline 1 & Sesuai anjuran & 3 & 5 & 15 \\
2 & Kurang sesuai & 2 & 32 & 64 \\
3 & Tidak sesuai & 1 & 13 & 13 \\
\hline \hline & Jumlah & 50 & 92 \\
\hline \hline
\end{tabular}

Sumber : Lampiran 2

\section{e. Teknik Panen}

Tabel 5 Respon petani terhadap pelaksanaan teknik panen dalam Program Kakao Berkelanjutan di Kabupaten Majene pada Tahun 2018.

\begin{tabular}{clccc}
\hline \hline No & \multicolumn{1}{c}{ Kriteria skor } & Skor & Responden & Jumlah Skor \\
\hline \hline 1 & Sesuai anjuran & 3 & 13 & 39 \\
2 & Kurang sesuai & 2 & 17 & 34 \\
3 & Tidak sesuai & 1 & 20 & 20 \\
\hline \hline & Jumlah & 50 & 93 \\
\hline \hline
\end{tabular}

Sumber : Lampiran 2

f. Teknik Sanitasi

Tabel 6 Respon petani terhadap pelaksanaan teknik sanitasi dalam Program Kakao Berkelanjutan di Kabupaten Majene pada Tahun 2018.

\begin{tabular}{clccc}
\hline \hline No & Kriteria skor & Skor & Responden & Jumlah Skor \\
\hline \hline 1 & Sesuai anjuran & 3 & 10 & 30 \\
2 & Kurang sesuai & 2 & 30 & 60 \\
3 & Tidak sesuai & 1 & 10 & 10 \\
\hline \hline & Jumlah & 50 & 100 \\
\hline \hline
\end{tabular}

Sumber : Lampiran 2 
Busmar : Dampak Program Kakao Berkelanjutan terhadap Pemberdayaan Petani dan Penguatan Kelompok Tani.

Tabel 7 Rekapitulasi Dampak Pelatihan dan Pemberdayaan Petani Program Kakao Berkelanjutan di Kabupaten Majene pada Tahun 2018.

\begin{tabular}{lcl}
\hline \hline \multicolumn{1}{c}{ Pelatihan } & Total Skor & Kriteria Skor \\
\hline \hline Teknik Pemupukan & & \\
Teknik Penanaman & 104 & Kurang Sesuai \\
Teknik Penyemprotan & 105 & Kurang Sesuai \\
Teknik Pemangkasan & 88 & Kurang Sesuai \\
Teknik Panen & 92 & Kurang Sesuai \\
Teknik Sanitasi & 93 & Kurang Sesuai \\
Total & 100 & Kurang Sesuai \\
\hline \hline
\end{tabular}

Sumber : Lampiran 2

Pada Tabel 7, menunjukkan bahwa Kategori tidak sesuai $=300-499$

tanggapan responden terhadap kegiatan Kategori kurang sesuai $=500-699$

pelatihan program kakao berkelanjutan Kategori sesuai $\quad=700-900$.

yaitu berada pada kategori kurang sesuai

dengan nilai total skor komulatif 582,

1. Kegiatan Bantuan Modal

a. Bantuan bibit

Tabel 8 Jumlah bantuan bibit program kakao berkelanjutan di Kabupaten Majene pada Tahun 2018.

\begin{tabular}{ccccc}
\hline \hline No & $\begin{array}{c}\text { Bantuan bibit } \\
\text { (Jumlah bibit ) }\end{array}$ & Responden & Persentase (\%) \\
\hline \hline 1 & $2.500-11.300$ & 22 & 88 \\
2 & $11.301-20.100$ & 2 & 8 \\
3 & $20.101-29.000$ & 1 & 4 \\
\hline \hline & Jumlah & & \\
\hline \hline & Maksimum & $: 29.000$ bibit & & \\
& Minimum & $: 2.500$ bibit & & \\
& Rata-Rata & $: 7.404$ bibit/kelompok & & \\
& & tani &
\end{tabular}

Sumber : Lampiran 3

Tabel 9 Kriteria penerima bantuan bibit program kakao berkelanjutan di Kabupaten Majene pada Tahun 2018.

\begin{tabular}{clccc}
\hline \hline No & \multicolumn{1}{c}{ Kriteria skor } & Skor & Responden & $\begin{array}{c}\text { Jumlah } \\
\text { Skor }\end{array}$ \\
\hline \hline 1 & Tidak sesuai & 1 & 0 & 0 \\
2 & Kurang sesuai & 2 & 0 & 0 \\
3 & Sesuai & 3 & 25 & 75 \\
\hline \hline & Jumlah & & 25 & 75 \\
\hline \hline
\end{tabular}

Sumber : Lampiran 
Busmar : Dampak Program Kakao Berkelanjutan terhadap Pemberdayaan Petani dan Penguatan Kelompok Tani.

b. Bantuan Modal Kerja

Tabel 10 Bantuan Upah Kerja Program Kakao Berkelanjutan di Kabupaten Majene pada Tahun 2018.

\begin{tabular}{cccc}
\hline \hline No & Bantuan upah kerja(Rp) & Responden & Persentase (\%) \\
\hline \hline 1 & $1.500 .000-10.666 .66$ & 22 & 88 \\
2 & $10.066 .667-19.833 .332$ & 2 & 8 \\
3 & $19.833 .334-29.000 .000$ & 1 & 4 \\
\hline \hline \multicolumn{5}{c}{ Jumlah } & 25 & 100 \\
\hline \hline \multicolumn{5}{c}{ Maksimum : 29.000 .000} & & \\
& Minimum : 1.500 .000 & & \\
& Rata-Rata : 5.465 .000 & \\
\hline \hline
\end{tabular}

Sumber : Lampiran 2

Tabel 11 Kriteria skor penerima bantuan upah kerja program kakao berkelanjutan di Kabupaten Majene pada Tahun 2018.

\begin{tabular}{clccc}
\hline \hline No & \multicolumn{1}{c}{ Kriteria skor } & Skor & Responden & Jumlah \\
\hline \hline & & & & Skor \\
1 & Tidak sesuai & 1 & 0 & 0 \\
2 & Kurang sesuai & 2 & 0 & 0 \\
3 & Sesuai & 3 & 25 & 75 \\
\hline \hline & Jumlah & & 25 & 75 \\
\hline \hline
\end{tabular}

Sumber : Lampiran

\section{Penguatan Kelembagaan Kelompok}

\section{Tani Kakao}

Untuk menguatkan kelembagaan

Kelompok Tani Kakao di Kabupaten Majene, maka dapat dilakukan melalui berbagai strategi. Strategi yang dapat digunakan disesuaikan dengan kondisi dan kapasitas kelompok tani Kakao. Adapun analisis yang digunakan adalah analisis $\mathrm{R}$ O N (Resource, Organisasi dan Norma).
1. Sumberdaya

Sumber Daya Pertanian merupakan suatu aspek yang penting dalam melakukan proses pertanian. Aspek-aspek tersebut saling berkaitan erat satu sama lain, sehingga berpengaruh besar terhadap produksi pertanian. Sumber daya pertanian yang berperan dalam pengolahan dan pengembangan produk pertanian, yaitu : 
Busmar : Dampak Program Kakao Berkelanjutan terhadap Pemberdayaan Petani dan Penguatan Kelompok Tani.

a. Pemupukan modal

Tabel 12 Respon petani tentang Pemupukan Modal Program Kakao Berkelanjutan di Kabupaten Majene pada Tahun 2018.

\begin{tabular}{clcc}
\hline \hline \multirow{2}{*}{ No } & \multirow{2}{*}{ Pemupukan Modal } & \multicolumn{2}{c}{ Program Kakao Berkelanjutan } \\
\cline { 3 - 4 } & & Sebelum & Setelah \\
\hline \hline 1 & Tidak ada & 50 & 50 \\
2 & Kadang-kadang & 0 & 0 \\
3 & Ada & 0 & 0 \\
\hline \hline & Jumlah & $\mathbf{5 0}$ & $\mathbf{5 0}$ \\
\hline \hline
\end{tabular}

Sumber: Lampiran 4, 7

b. Pengetahuan dan Keterampilan Petani

Tabel 13 Frekuensi Mengikuti PenyuluhanProgram Kakao Berkelanjutan di Kabupaten Majene pada Tahun 2018.

\begin{tabular}{clcc}
\hline \hline \multirow{2}{*}{ No } & \multirow{2}{*}{ Frekuensi Mengikuti Penyuluhan } & \multicolumn{2}{c}{ Program Kakao Berkelanjutan } \\
\cline { 3 - 4 } & & Sebelum & Setelah \\
\hline \hline 1 & Tidak Pernah & 36 & 0 \\
2 & Kadang-Kadang & 0 & 0 \\
3 & Sering & 14 & 50 \\
\hline \hline & Jumlah & $\mathbf{5 0}$ & $\mathbf{5 0}$ \\
\hline \hline
\end{tabular}

Sumber : Lampiran 4, 7

c. Akses Informasi

Tabel 14 Sumber Informasi Program Kakao Berkelanjutan di Kabupaten Majene pada Tahun 2018.

\begin{tabular}{clcc}
\hline \hline \multirow{2}{*}{ No } & \multicolumn{2}{c}{ Sumber Informasi } & \multicolumn{2}{c}{ Program Kakao Berkelanjutan } \\
\cline { 3 - 4 } & & Sebelum & Setelah \\
\hline \hline 1 & Sesama petani & 46 & 13 \\
2 & Media elektronik & 2 & 0 \\
3 & Penyuluh & 2 & 37 \\
\hline \hline & Jumlah & $\mathbf{5 0}$ & $\mathbf{5 0}$ \\
\hline \hline
\end{tabular}

Sumber : Lampiran 4, 7

2. Organisasi/Manajemen

a. Kemampuan Kelompok Tani

Tabel 15 Kelas Kemampuan Kelompok TaniProgram Kakao Berkelanjutan di Kabupaten Majene pada Tahun 2018.

\begin{tabular}{|c|c|c|}
\hline No & " Kelas Kemampuan Kelompok Tani & Jumlah KT \\
\hline 1 & Pemula & 0 \\
\hline 2 & Lanjut & 0 \\
\hline 3 & Madya & 25 \\
\hline \multirow[t]{2}{*}{4} & Utama & 0 \\
\hline & Jumlah & 25 \\
\hline
\end{tabular}

Sumber : Lampiran 5, 8 
Busmar : Dampak Program Kakao Berkelanjutan terhadap Pemberdayaan Petani dan Penguatan Kelompok Tani.

b. Struktur Organisasi

Tabel 16 Kelengkapan Organisasi AD/ART Program Kakao Berkelanjutan di Kabupaten Majene pada Tahun 2018.

\begin{tabular}{clcc}
\hline \hline \multirow{2}{*}{ No } & \multirow{2}{*}{ Kelengkapan Organisasi AD/ART } & \multicolumn{2}{c}{ Program Kakao Berkelanjutan } \\
\cline { 3 - 4 } & Tidak ada & Sebelum & Setelah \\
\hline \hline 1 & Ada dan sederhana & 10 & 0 \\
3 & Ada dan lengkap & 15 & 10 \\
\hline \hline & Jumlah & 0 & 15 \\
\hline \hline Sumber $:$ Lampiran 5,8 & $\mathbf{2 5}$ & $\mathbf{2 5}$ \\
\hline
\end{tabular}

Sumber : Lampiran 5, 8

c. Fungsi dan Peran pengurus

Tabel 17 Fungsi dan Peran pengurus Program Kakao Berkelanjutan di Kabupaten Majene pada Tahun 2018.

\begin{tabular}{clcc}
\hline \hline \multirow{2}{*}{ No } & \multirow{2}{*}{ Fungsi dan Peran pengurus } & \multicolumn{2}{c}{ Program Kakao Berkelanjutan } \\
\cline { 3 - 4 } & & Sebelum & Setelah \\
\hline \hline 1 & Tidak berperan & 10 & 0 \\
2 & Kurang Berperan & 13 & 19 \\
3 & Sangat Berperan & 27 & 31 \\
\hline \hline & Jumlah & $\mathbf{5 0}$ & $\mathbf{5 0}$ \\
\hline \hline
\end{tabular}

Sumber : Lampiran 5, 8

\section{Norma}

a. Kerjasama/Gotongroyong

Tabel 18 Kerjasama/GotongroyongProgram Kakao Berkelanjutan di Kabupaten Majene pada Tahun 2018.

\begin{tabular}{|c|c|c|c|}
\hline \multirow{2}{*}{ No } & \multirow{2}{*}{ Kerjasama/Gotongroyong } & \multicolumn{2}{|c|}{ Program Kakao Berkelanjutan } \\
\hline & & Sebelum & Setelah \\
\hline 1 & Tidak ada & 0 & 0 \\
\hline 2 & Kadang-Kadang & 15 & 10 \\
\hline 3 & Selalu/sering & 35 & 40 \\
\hline & Jumlah & 50 & 50 \\
\hline
\end{tabular}

Sumber : Lampiran 6, 9

b. Pembagian Tugas dalam Kelompok Tani

Tabel 19 Pembagian Tugas dalam KelompokProgram Kakao Berkelanjutan Tani di Kabupaten Majene pada Tahun 2018.

\begin{tabular}{|c|c|c|c|}
\hline \multirow{2}{*}{ No } & \multirow{2}{*}{$\begin{array}{c}\text { Pembagian Tugas dalam Kelompok } \\
\text { Tani } \\
\end{array}$} & \multicolumn{2}{|c|}{ Program Kakao Berkelanjutan } \\
\hline & & Sebelum & Setelah \\
\hline 1 & "Tidak ada & 8 & 0 \\
\hline 2 & Ada, namun tidak jelas & 13 & 15 \\
\hline 3 & Ada dan sangat jelas & 24 & 35 \\
\hline & Jumlah & 50 & 50 \\
\hline
\end{tabular}

Sumber: Lampiran 6, 9 
Berdasarkan pembahasan tentang terhadap penguatan kelompok tani, dapat dampak Program kakao berkelanjutan dilihat sebagai berikut.

Tabel 20 Rekapitulasi kegiatan penguatan kelompok tani Program Kakao Berkelanjutan Tani di Kabupaten Majene pada Tahun 2018.

\begin{tabular}{|c|c|c|}
\hline No & Kegiatan penguatan kelompok tani & Hasil \\
\hline 1 & Pemupukan Modal & $\begin{array}{l}100 \% \text { responden tidak melakukan } \\
\text { pemupukan modal }\end{array}$ \\
\hline 2 & Pengetahuan dan Keterampilan & $\begin{array}{l}\text { Seluruh responden } \\
\text { penyuluhan pertanian }\end{array}$ \\
\hline 3 & Akses Informasi & $\begin{array}{l}\text { Sumber informasi tentang kakao } \\
\text { berkelanjutan lebih banyak dari } \\
\text { penyuluh }\end{array}$ \\
\hline 4 & Kemampuan Kelompok Tani & $\begin{array}{l}\text { Semua kelompok tani termasuk kelas } \\
\text { madya }\end{array}$ \\
\hline 5 & Struktur Organisasi & $\begin{array}{l}50 \% \text { kelompok memiliki kelengkapan } \\
\text { organisasi tersedia dan lengkap }\end{array}$ \\
\hline 6 & Fungsi dan Peran Pengurus & 31 responden sangat berperan \\
\hline 7 & Kerjasama / Gotongroyong & $\begin{array}{l}40 \text { responden aktif melakukan kegiatan } \\
\text { kerjasama dan gotong royong }\end{array}$ \\
\hline 8 & Pembagian Tugas dalam Kelompok & $\begin{array}{l}\text { Terdapat pembagian tugas dan sangat } \\
\text { jelas dalam kelompok tani }\end{array}$ \\
\hline
\end{tabular}

Sumber : Data Primer, 2018

Berdasarkan Tabel 23, dampak Kakao berkelanjutan terhadap penguatan kelompok tani bahwa setelah mengikuti program kakao berkelanjutan. Maka terjadi peningkatan penguatan kelompok tani ditinjau dari aspek (Resource, Organisasi, Norma)

\section{KESIMPULAN DAN SARAN}

\section{Kesimpulan}

1. Pelaksanaan Program Kakao berkelanjutan meliputi pemupukan, penanaman, penyemprotan, pemanenan, pemangkasan, sanitasi bantuan bibit dan upah kerja.
2. Dampak program kakao berkelanjutan terhadap kegiatan pelatihan adalah responden melaksanakan kegiatan pemupukan,penanaman, penyemprotan, pemanenan, pemangkasan, dan sanitasi kurang sesuai dengan materi pelatihan. Dampak program kakao berkelanjutan terhadap, bantuan bibit adalah 7.404 pohon/kelompok tani dan bantuan modal untuk upah kerja adalah Rp 5. 465.000/ kelompok. Dampak program kakao berkelanjutan terhadap penguatan kelompok tani adalah tidak ada pemupukan modal, aktif mengikuti penyuluhan, penyuluh aktif memberi 
informasi.kelas kemampuan kelas Friedmann, J. 1992. Empowerment. The madiya, kelengkapan organisasi suda ada, sudah ada fungsi dan peran pengurus, kegiatan gotong royong sudah terlaksana dan sudah ada pembagian tugas dalam kelompok tani.

\section{Saran}

Pelaksanaan Program kakao

berkelanjutan melalui kegiatan, untuk terus dilanjutkan secara berkesinambungan, sehingga menghasilkan produktivitas bagi para petani kakao. Melalui Program kakao berkelanjutan, dengan sendirinya akan terwujud kerjasama yang solid antara kelompok tani dalam meningkatkan hasil usahatani melalui kegiatan pelatihan dan pendampingan, serta meningkatkan pendapatan dan kesejahteraan petani di Kabupaten Majene.

\section{DAFTAR PUSTAKA}

Amanah, Siti dan Narni Farmayanti. 2014. Pemberdayaan Sosial Petani-Nelayan, Keunikan Agroekosistem, dan Daya Saing. Yayasan Pustaka Obor Indonesia. Jakarta

Darmawan, Deni. 2006. Dasar-dasar Teknologi Informasi dan Komunikasi, Upi. Press,Bandung.

Djalaluddin A, 2007. Pemanfaatan Kulit Buah Kakao Sebagai Pengganti Hijauan Dalam Ransum Ternak Kambing. Program Sarjana. Fakultas Perternakan. Universitas Jambi. politics of an alternative development. Oxford. Basil Blackwell. xii+196 pp.

Hermanto, $\quad$ Swastika. 2012. Pemberdayaan: Konsep, Kebijakan dan Implementasi. Jakarta: Center for Strategic and International Studies

Karmawati, E. et al. 2010. Budidaya dan Pasca Panen Kakao. Pusat Penelitian dan Pengembangan Perkebunan. 92 hal.

Kartasapoetra, A.G. 1994. Teknologi Penyuluhan Pertanian. Jakarta : Bumi Aksara.

Kartasasmita, Ginjar, 1995. Pemberdayaan Masyarakat Sebuah Tinjauan Administrasi. Pidato Pengakuan Jabatan Guru Besar Dalam Ilmu Administrasi Pada Fakultas Ilmu Administrasi. Universitas Brawijaya, Malang.

Marijn et al. 2007.Fermented Foods, Part I: Biochemistry and Biotechnology. Vol. 2.

Nasdian. 2014. Pengembangan Masyarakat. Yayasan Obor Indonesia

Nasrul B, Hamzah. A, Edison Anom. 2012. Klasifikasi Tanah Dan Evaluasi Kesesuaian Lahan Kebun Percobaan Fakultas Pertanian UNRI. Jumal Sagu Agriculture Science and Technologi. Vol. 2. Pekanbaru

Nasrun, T Arwiyanto dan I Mariska. 2008. Pemanfaatan Produk Pseudomonad fluoresen sebagai Agens Pengimbas Ketahanan Tanaman Dalam Mengendalikan Penyakit Layu Bakteri dan Meningkatkan Pertumbuhan Nilam. Status Teknologi Hasil Penelitian Nilam Tahun 2008. Kementrian Riset dan Teknologi. 48 hlm.

Spillane, J. 1995. Komoditi Kakao, Peranannya dalam Perekonomian Indonesia. Kanisius.Yogyakarta. 

Kelompok Tani.

Soetomo. 2013. Transformasi Model Penyuluhan Pertanian Menuju Pengembangan Kemandirian Petani. Program Pascasarjana Institut Pertanian Bogor, Bogor

Sumardjo dan Saharudin, 2006, Tajuk Modul EP-523 : Metode-metode. Partisipatif dalam Pengembangan Masyarakat, Departemen Komunikasi dan Pengembangan Masyarakat, Fakultas Ekologi Manusia IPB

Sumarti et al. 2006. Ekstraksi Komponen Bioaktif Dari Limbah Kulit Buah Kakao dan Pengaruhnya terhadap
Aktivitas Antioksidan Dan Antimikroba. Program Pascasarjana. Universitas Andalas.

Wahyudi, T., Panggabean, T.R., \& Pujianto, 2008, Panduan Lengkap Kakao, 13, Jakarta, Penebar Swadaya.

Widjajanti, HAW. 2011. Otonomi Desa Merupakan Otonomi Asli Bulat dan Utuh. PT. RajaGrafindo Persada,Jakarta.

Yustika.2008. Peranan Birokrasi dalam Pemberdayaan Masyarakat. ALFABETA, Bandung. 